\title{
BMJ Open The current provision of community- based teaching in UK medical schools: an online survey and systematic review
}

\author{
Sandra W W Lee, ${ }^{1}$ Naomi Clement, ${ }^{1}$ Natalie Tang, ${ }^{1}$ William Atiomo ${ }^{2}$
}

To cite: Lee SWW,

Clement N, Tang N, et al.

The current provision of community-based teaching in UK medical schools: an online survey and systematic review. BMJ Open 2014;4: e005696. doi:10.1136/ bmjopen-2014-005696

- Prepublication history for this paper is available online. To view these files please visit the journal online (http://dx.doi.org/10.1136/ bmjopen-2014-005696).

Received 14 May 2014 Revised 12 September 2014 Accepted 6 November 2014

CrossMark

\begin{abstract}
${ }^{1}$ School of Medicine, University of Nottingham, Queen's Medical Centre, Nottingham, UK ${ }^{2}$ Clinical Sub-Dean, School of Medicine, University of Nottingham, Nottingham, UK
\end{abstract}

Correspondence to Naomi Clement; msxnc@nottingham.ac.uk

\section{ABSTRACT}

Objective: To evaluate the current provision and outcome of community-based education (CBE) in UK medical schools.

Design and data sources: An online survey of UK medical school websites and course prospectuses and a systematic review of articles from PubMed and Web of Science were conducted. Articles in the systematic review were assessed using Rossi, Lipsey and Freeman's approach to programme evaluation. Study selection: Publications from November 1998 to 2013 containing information related to community teaching in undergraduate medical courses were included.

Results: Out of the 32 undergraduate UK medical schools, one was excluded due to the lack of course specifications available online. Analysis of the remaining 31 medical schools showed that a variety of CBE models are utilised in medical schools across the UK. Twenty-eight medical schools $(90.3 \%)$ provide CBE in some form by the end of the first year of undergraduate training, and 29 medical schools $(93.5 \%)$ by the end of the second year. From the 1378 references identified, 29 papers met the inclusion criteria for assessment. It was found that CBE mostly provided advantages to students as well as other participants, including GP tutors and patients. However, there were a few concerns regarding the lack of GP tutors' knowledge in specialty areas, the negative impact that CBE may have on the delivery of health service in education settings and the cost of CBE.

Conclusions: Despite the wide variations in implementation, community teaching was found to be mostly beneficial. To ensure the relevance of CBE for 'Tomorrow's Doctors', a national framework should be established, and solutions sought to reduce the impact of the challenges within CBE.

Strengths and limitations of this study: This is the first study to review how community-based education is currently provided throughout Medical Schools in the UK. The use of Rossi, Lipsey and Freeman's method of programme evaluation means that the literature was analysed in a consistent and comprehensive way. However, a weakness is that data from the online survey was obtained from online medical school prospectuses. This means the data may be incomplete or out of date. Data in the literature review may also be skewed by publication bias.

\section{INTRODUCTION}

The context of healthcare in the UK is changing, with an increasingly aging population and a growing focus on the prevention and management of disease. ${ }^{1}$ This has prompted the need to ensure that medical graduates are adequately prepared to address these evolving healthcare needs, rather than maintaining a reactive approach to illness in the UK. These needs include the prevention and management of chronic health conditions such as diabetes, heart disease, cancer and other long-term illnesses. The promotion of health as well as the delivery of care of conditions like these often occurs within the community, outside the context of University teaching hospitals, provided by professionals from several disciplines, including a significant input from social services. In the recently published UK government's white paper, Equity and Excellence: Liberating the National Health Service (NHS), ${ }^{2}$ a need for a healthcare system focused on personalised care reflecting individuals' health and care needs was outlined. This would involve supporting carers and encouraging multidisciplinary care. These social demographic and political drivers require strong input from multiprofessional healthcare providers in primary care and the recruitment of more general practitioners (GPs) in order to fulfil the growing need for community-based care.

This concept also resonates globally and is considered important by health regulatory bodies that license medical schools. In 1987, the WHO recommended the reform of health professional curricula by incorporating methods to prepare students for providing care at all levels of healthcare settings, ${ }^{3}$ which can be achieved by, among other things, aligning education with community needs. The UK General Medical Council's (GMC's) document 'Tomorrow's Doctors' recommend that clinical placements should reflect the changing patterns of healthcare 
and that they must provide experience in a variety of environments including hospitals, general practices and community medical services. ${ }^{4}$

Curricula in the UK medical schools, therefore, currently offer community-based education (CBE) in various forms and models of teaching. ${ }^{5} \mathrm{CBE}$ is defined as a medical education programme that may employ any variety of teaching methods to promote an understanding of health concerns at a community level. The programme is set within the community, and involves individuals within the community.

Previous publications have evaluated these models of medical teaching in the community, including analyses of their advantages and drawbacks. ${ }^{6-28}$ However, a thorough literature search (as conducted in November 2013) found no existing systematic reviews on community-based teaching across all existing UK medical schools. It remains unclear what the extent of community-based teaching in UK medical schools is, the impact this had made to the standards of healthcare, and how the effectiveness of community-based teaching programmes has been measured. Knowledge of this is considered important, as it would guide the structuring of undergraduate medical curricula to adapt to changing contexts in the UK, hence effectively developing a future generation of doctors who are appropriately prepared for upcoming healthcare needs. The aim of this study, therefore, was to conduct an online survey of the current provision of community-based teaching within UK undergraduate medical schools to appreciate the extent of implementation. A systemic review was also conducted to comprehensively evaluate community-based teaching in UK medical curricula on the domains of programme needs, implementation, impact, and cost.

\section{METHODS}

\section{Online survey}

An online survey of the current provision of communitybased teaching in UK medical curricula was completed by NC through accessing official online material of medical schools between 31 November 2013 and 8 December 2013. An up-to-date list of all the registered medical schools was obtained from the Medical Schools Council (MSC) website on 31 November 2013. ${ }^{29}$ All graduate-entry courses were excluded. This was due to the wide variations of graduate-entry course structure, as well as the lack of literature on postgraduate community-based medical education. This was a prerequisite in order for the results of both the online survey and systematic review to be evaluated in parallel.

Online material of the undergraduate medical curriculum was sourced using the Google search engine, and included content from university websites or online course prospectuses for the 2014 intake. The information search was specific to descriptions of both mandatory and elective components of the curriculum relating to 'primary care', 'general practice', or 'community medicine'.

\section{Systematic review: data sources}

A systematic literature review was conducted using the electronic databases PubMed and Web of Science to source for papers published on undergraduate community-based medical education. With the understanding that community-based education has evolved over the years, only publications published within the past 15 years, from November 1998 to 2013, were included in this study. The search criteria was ('community-based', 'communityoriented', 'community involvement', or; 'primary health care') and ('medical curriculum', 'medical students', 'undergraduate medical education' or 'undergraduate medical school').

\section{Systematic review: selection criteria and data extraction}

The relevance of the articles was screened by the title and abstract, based on the inclusion and exclusion criteria. Articles were selected if they described undergraduate medical education within the UK. Papers that included healthcare professionals apart from medical students were excluded. Any articles that were duplicated, not available in full text, or not published in English were also regarded as unsuitable for the review. In total, 29 peer-reviewed articles were identified as relevant, and were selected for further qualitative content analysis by SL and NT (see figure 1). Data on the following were extracted from each article: (1) Format of CBE; (2) Type of evaluation used to assess the programme; (3) Findings of this evaluation; and (4) Method of data collection. Rossi, Lipsey and Freeman's (2004) approach to programme evaluation was adopted to systematically categorise the evaluation findings on CBE (see table 1). The domains applicable to this study were the needs assessment, implementation assessment, impact assessment and cost assessment. The impact assessment was further subcategorised into the impact on students (target population of $\mathrm{CBE}$ ), and the impact on others involved in CBE programmes.

Abstraction of data was performed independently by reviewers SL and NT. Themes were also independently drawn from data analysis of the impact assessments on students. Disagreements between the two reviewers were resolved by arriving at a consensus.

\section{RESULTS}

\section{Current provision of community-based teaching in UK medical schools}

We were able to obtain information from the medical school websites about the provision of community-based teaching in all 32 undergraduate medical schools, and this is outlined in table 2 and summarised in table 3 . All undergraduate medical schools provided some form of community-based teaching or placement. There was, however, variation in the structure, duration and time in the course when community teaching was delivered (see tables 2 and 3). CBE mainly took the form of clinical placements, patient studies and optional modules. 
Search Syntax:

("community oriented" OR "community based" OR "community involvement" OR "community teaching") AND ("medical student" OR "medical curriculum" OR "undergraduate medical education" OR "medical school” OR "medical university" OR undergraduate medical teaching")

From: 1998 to 2013

Exclusion criteria:

- Non-English articles

- Articles not related to the UK

- No full-text (digital or hard copy in the University of Nottingham Library) available

- Non-undergraduate medical programmes

- Articles involving other medical professionals other than medical students
Deleting duplicates

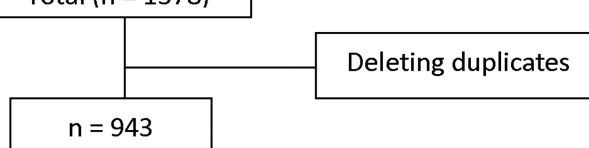

Table 1 Domains in Rossi, Lipsey and Freeman's approach to programme evaluation

\section{Domains of programme evaluation}

Needs assessment

'Logic Model' assessment (of programme conceptualisation and design

Implementation assessment

Impact assessment

Efficiency assessment undertaken in Brighton \& Sussex). Analysis of the varying formats of CBE (with the exclusion of Norwich, due to the lack of year-by-year curriculum details) revealed that most medical schools (a total of 31) provide early exposure to general practice or community 
1 Aberdeen (University of)

2 Barts and The London School of Medicine and Dentistry, Queen Mary, University of London

3 Birmingham (University of)

$4 \quad$ Brighton and Sussex Medical Schoo

5 Bristol (University of

6 Cambridge (University of

$7 \quad$ Cardiff University

8 Dundee (University of)

9 Durham (University of)

10 Edinburgh (The University of)

11 Exeter (University of)

12 Glasgow (University of

13 Hull York Medical School
Year 1-The 'Community Course': including General Practice, Public Health, Mental Health, Environmental and Occupational Medicine, Health Care of the Elderly, and Paediatrics; allowing learning about the social, economic and environmental impacts on health

Year 2-The 'Community Course' continues

Year 3-The 'Community Course' is completed

Year 4-5 week general practice placement

Year 5-8-week blocks of: (1) a medical specialty, (2) a surgical specialty, (3) a general practice or psychiatry course, (4) an elective and (5) a 'Professional Practice' block

Years 1 \& 2-Regular general practice placements

Years 3 \& 4-Work with clinical teams in the hospital and also within community placements

Year 5 -Clinical and community placements, including general practice surgeries

Years 1 \& 2-10 days per year spent in general practice

Year 3-Community-based medicine module

Years 4 \& 5-One general practice attachment within these 2 years

Years $1 \& 2-25 \%$ of learning is clinically based including experience in primary care, community medicine and out-patient settings. Patients do two family studies: One in year 1 ('family with a new baby'), and one in year 2 ('the chronic illness patient').

Years 3 \& 4-A year-long module on primary care and population medicine, alongside clinical placements in hospital trusts and primary care

Year $1-$ General Practice and patient home visits

Year 2-Clinical skills teaching in the primary care setting

Year 3-Teaching in hospitals and in general practice

Year 4-Two 'Community Orientated Medical Practice' modules

Year 4-Two 'Communily Orientated Medical Praclice' modules

Years 1 - Meet pationts in the general practice.

Years 1 - 3 -

Yeas 2 \& 3 -

throughout pregnancy (year 3 project). Students also have primary care teaching in the following:

- Module on the 'Clinical Method' involves time spent in primary care, including teaching

Module on 'The Life Course' involves time spent in primary and community care. Learning is focused on how diseases present, are managed and the patients' perspective

Module on 'Preparation for Practice' involves one general practice attachmen

Year $1-12$ week introductory programme involving short clinical experience days in general practice

Years 1 \& 2-one day a week seeing patients in hospitals, general practice or other community-based senvice.

Year $5-8$ week placement in the community

'Doctors, Patients and Communities' course runs throughout the undergraduate medical programme, allowing early patient contact. This course includes public health and primary care. Students submit a record of clinical experience

Years 4 \& 5-Primary care attachments, with an option to extend the 5th year primary care attachment to 2 or 3 months

Years 1 \& 2-Community-based teaching in:

- The 'Patient Study' module involves observing the effect of a chronic condition on a person and their immediate family in primary care and the community

The 'Family Project' follows a pregnant woman and then the effect of having a new baby in a family

- The 'Community Placement' with a variety of health and social care agencies, observing inter-professional and inter-agency working within the community. It may involve visiting patients at home and within primary care

Years 3-5-Medical programme completed at Newcastle University

Years 1 \& 2-Student have community projects, general practice-based teaching and three student selected projects on a range of topics (can be clinical Years 1 \& 2-Student

Years 3 \& 4-'Further clinical experience' (clinical setting not specified)

Years 3 \& 4-'Further clinical experience' $(c l i n i c$
Year 5-One placement in general practice

Year 5-One placement in general practic 1 \& 2-Community placements

Years 3 \& 4-Meet patients at home, in general practices, in acute and community hospitals

Year 5-One community placemen

First 15 weeks of Year 3-Students develop clinical skills in the hospital and general practice environment

Second half of Year 3, years 4 \& 5-One general practice placement

Students alternate between a hospital and primary care setting in all clinical placements

Year 1-Half a day each week on clinical placement

Year 2-One day each week on clinical placement

Years 3 \& 4-Clinical placements in general practice and hospitals

Year 5-Medical student is treated as a junior member of the medical team. Students have a general practice rotation, in which they see patients and perform routine medical procedures under the supervision of the general practice 
14 Imperial College School of Medicine

15 Keele University

16 King's College London School of Medicine (at Guy's, King's College and St Thomas' Hospital)

17 Lancaster University

18 Leeds (University of)

19 Leicester (University of)

20 Liverpool (University of)

21 Manchester (University of)

22 Newcastle University Medical School

23 Norwich Medical School, University of East Anglia

24 Nottingham (The University of)

25 Oxford (University of)

26 Plymouth University, Peninsula Schools of Medicine and Dentistry
Years 1 \& 2- 'The 'Patient Contact Course' (for chronic illnesses) involve students getting attached to one patient/family and visiting them at their homes and in the clinical setting. Learning is supplemented by general practice and hospital visits

Year 3-Learning basic clinical skills and methods in general practice

Year 5-One general practice and Primary Health Care placement

Year 6-3 week 'general practice Student Assistantship' placement

Year 1-Placements in general practice setting

Year 2-Students select a 'third sector' placement from a range of community organisations

Year 3-4 weeks spent consolidating clinical skills in general practice surgery

Year 4-4 weeks in general practice, as well as an option of a special study component in general practice

Year 5-Longer general practice placement. Students also work in small groups to identify community needs

Inter-professional education is embedded in the medical curriculum throughout the duration of the course

Year 1 (term 1)-Students have their first experiences of primary care (visiting general practice and interviewing patients) and hospital

Phase 2 ( 3 terms) - Continuing clinical contact in primary care attachments and general practice visits

Phase 3 ( 3 terms)-Students study basic skills with a general practice tutor. Each of the three placements involve community attachments

Phase 4 (3 13-weeks rotations)-A 'Community and Applied-Health Promotion Study' is performed following a pregnant women and her family.

Students also continue multidisciplinary team learning

Phase 5 (final year)-One 8 week attachment in general practice and community

Year 1 -Students have a community attachment in the second term with health visitors

Year 1 - Students have a community attachm

Dersesment

Year 3-One general practice placement with a focus on disability

Year 4-One day per week in general practice

Year 1-'Campus to Clinic' module (lasting half the academic year): students work in a healthcare team for 1 day per week, rotating between primary and secondary care. Medical students also arrange a community visit to a healthcare voluntary group close to their practice

Year 2-'Campus to Clinic' module (lasting half the academic year)

Year 3-5 week primary care placement

Year 5 -One placement (8 weeks) involves integrating teaching between primary and secondary care

Phase 1 (First 5 Terms)-Community attachments are undertaken to gain experience of the social implications of medicine. Study of social and

behavioural sciences supplements these placements

Phase 2-Time is spent in 'innovative community attachments' to allow learning of the multidisciplinary team

Years 2-5-Hospital and community-based clinical experiences

Year 1-Community visits

Year 3-Community placements related to certain modules

Year 4-Community and primary care teaching on further modules

Year 5-Students work as part of the team in general practice, community paediatrics or community psychiatry, running their own consultations and Year

Year 1 \& $2-$ Ealy clinical expe

experience with full and half-days spent in general practices practices and hospital visits. Students also do 2 patient studies: One 'family study project' and one in-depth study of a patient with chronic illness

Year 3- Half a day each week spent in general practice

Year 5-Primary Care clinical rotation including out-of-hours calls with general practices

NB: No year-by-year information given.

'Regular placements in hospital and general practice allow students to observe the full range of patient care'

Years 1 \& 2-One morning every month spent with a GP

Year 3-'Community Follow Up Project' (starting in year 2) is completed. Projects involves following an assigned patient for 18 months, and learning about the effects of the patients care on the patient and their family

Year 4-One week community attachment during obstetrics and gynaecology placement and 1 day spent with a community midwife. Regular community visits during paediatrics attachment (general practice, Community Paediatrician, Health Visitor or School Nurse). Students are also given an option of a special study module in primary care

Year 5 -One 5 week general practice placement

Years 1 \& 2-Meeting patients in general practice

Year 4-Meeting patients in the general practice (2 weeks) and a residential attachment at the general practice (1 week)

Year 5-One community placement (in clinical geratology, dermatology, palliative care, primary healthcare or public/ population health)

Year 6-Optional 12-week special study module in primary care

Year 1-Weekly practical community based work throughout the course, inclusive of 'Sure Start' or drug clinic visits

Year 2-General practice practice visits on 6 separate days

Year 3 \& 4-Students can see patients themselves in supervised settings in a general practice during a week-long placement, three times in each year Year 5 - 6 week long the general practice placement 


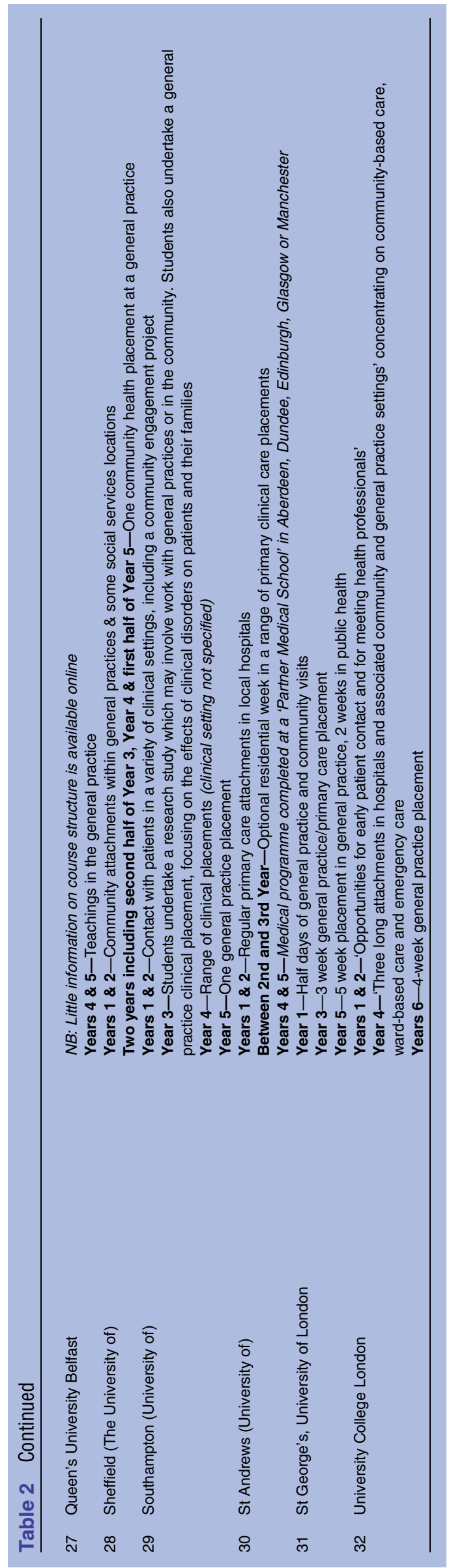

teaching. Twenty-eight medical schools $(90.3 \%)$ provide community teaching from the first year of undergraduate medical education. By the end of the second year of preclinical education, students of 29 medical schools $(93.5 \%)$ would have received some form of communitybased teaching.

The most popular form of community-based teaching within medical schools was general practice placements with $83.9 \%$ (26 schools from a total of 31) providing general practice placements within the first 2 years of study. Patient studies were the least common form of placements. These were defined as projects where students visited patients within the community or at home. Only $38.7 \%$ (12 schools) provided this format of community education at some point in their courses.

Fourteen (45.2\%) medical schools provided regular exposure to community teaching in every year or phase of the course.

With regards to optional modules offered to students, only three of the medical schools offered them-9.7\% . This implies that, if students are particularly interested in community care, they may find it difficult to achieve extra studies in this area.

\section{Literature review of studies evaluating community-based teaching}

A summary of the studies evaluated in the systematic literature review are outlined in table 4. The main methods of evaluation employed in the studies were questionnaires, interviews and focus groups of the key stakeholders in CBE-students, patients, tutors and other staff in the community setting.

\section{Needs assessment of CBE}

Studies of student expectations of CBE highlighted that students valued experiential patient-centred learning and tutor supervision in the community setting. ${ }^{14}{ }^{30}$ In a Sheffield study, ${ }^{14}$ students also recognised that CBE was a powerful vehicle for changing their approach to medicine and illness, where the patient as a person is given emphasis over the disease.

\section{Implementation assessment of CBE}

All forms of community-based teaching were generally well-received by medical students, patients and participating healthcare professionals, supporting the continuation of existing community-based teaching programmes in the future. This included community-based teaching which was incorporated into specialty modules such as Obstetrics and Gynaecology, ${ }^{31}$ Psychiatry ${ }^{22}$ and Surgery. ${ }^{27}$ The unique approach of incorporating primary healthcare in an intercalated Bachelor of Science medical research year also received positive feedback. ${ }^{23}$

Three studies found that students preferred the implementation of practice-based teaching over hospital-based teaching. Hastings $e t a l^{11}$ found that students in Leicester preferred practice-based teaching on the grounds of both teaching method and content. O'Sullivan et $a l^{12}$ had 
Table 3 Summary of findings from online survey

\begin{tabular}{|c|c|c|c|c|c|c|c|}
\hline & & \multicolumn{6}{|c|}{ Year of study } \\
\hline \multicolumn{2}{|c|}{ Medical school } & \multirow{2}{*}{$\begin{array}{l}\text { 1st } \\
, 8\end{array}$} & \multirow{2}{*}{$\frac{\text { 2nd }}{2,8}$} & \multirow{2}{*}{$\frac{3 \text { rd }}{8,8}$} & \multirow{2}{*}{$\begin{array}{l}\text { 4th } \\
0\end{array}$} & \multirow{2}{*}{ 5th } & \multirow{2}{*}{$\begin{array}{l}\text { 6th } \\
\text { NA }\end{array}$} \\
\hline 1 & Aberdeen & & & & & & \\
\hline 2 & Barts and Queen Mary & 0 & 0 & , 8 & , 8 & , 8 & NA \\
\hline 3 & Birmingham & 0 & 0 & 8 & 0 & 0 & NA \\
\hline 4 & Brighton and Sussex & , 8,P & , 8,P & , 8 & , 8 & & NA \\
\hline 5 & Bristol & O, P & 8 & 0 & 8 & 0 & NA \\
\hline 6 & Cambridge & 0 & , 8,P & , 8,P & & & \\
\hline 7 & Cardiff & 0 & 0,8 & & & 8 & NA \\
\hline 8 & Dundee & , 8 & 8 & , 8 & , 8 & , 8 & NA \\
\hline 9 & Durham (years 3-5 completed in Newcastle) & , $8, P$ & , 8,P & NA & NA & NA & NA \\
\hline 10 & Edinburgh & O, P & O, P & & & 0 & NA \\
\hline 11 & Exeter & , 8 & , 8 & , 8,P & , 8,P & 8 & NA \\
\hline 12 & Glasgow & & & 0 & 0 & 0 & NA \\
\hline 13 & Hull York & , 8 & , 8 & ○ & 0 & 0 & NA \\
\hline 14 & Imperial College & , $8, P$ & , $8, P$ & ○ & & 0,8 & 0 \\
\hline 15 & Keele & 0 & 8 & 0 & $x$ & 0 & NA \\
\hline 16 & King's College London & , 8,P & , 8 & , 8 & $\mathrm{P}$ & , 8 & NA \\
\hline 17 & Lancaster & 8 & 8 & 0 & 0 & 8 & NA \\
\hline 18 & Leeds & , 8 & 0,8 & , 8 & , 8 & , 8 & NA \\
\hline 19 & Leicester & , 8 & , 8 & , 8 & , 8 & 0,8 & NA \\
\hline 20 & Liverpool & & 8 & 8 & 8 & 8 & NA \\
\hline 21 & Manchester & 8 & & 8 & , 8 & , 8 & NA \\
\hline 22 & Newcastle & O, P & O, P & 0 & & 0 & NA \\
\hline 23 & Norwich & $\begin{array}{l}\text { no year- } \\
\text { placeme }\end{array}$ & $\begin{array}{l}\text { year brea } \\
\text { reported }\end{array}$ & $w n-r e g$ & general & & \\
\hline 24 & Nottingham & 0 & $\mathrm{O}, \mathrm{P}$ & $P$ & , 8 & 0 & NA \\
\hline 25 & Oxford & O,P & O,P & & O,P & 8 & $\times$ \\
\hline 26 & Plymouth & 8 & 0 & ○ & - & 0 & NA \\
\hline 27 & Queen's University Belfast & & & & 0 & 0 & NA \\
\hline 28 & Sheffield & , 8 & 0,8 & & 0 & 0 & NA \\
\hline 29 & Southampton & $8, \mathrm{P}$ & , $8, \mathrm{P}$ & , $8, \mathrm{P}$ & & 0 & NA \\
\hline 30 & St Andrews (years 4-5 completed in Manchester) & 8 & $8, \times$ & & NA & NA & NA \\
\hline 31 & St George's, University of London & 8 & & , 8 & & 0,8 & NA \\
\hline 32 & University College London & , 8 & & & , 8 & 0 & NA \\
\hline
\end{tabular}

similar findings among students from University College London, where practice-based teaching bore qualities of better teaching attitudes, teaching methods and course organisation. Interestingly, these findings were consistent with Powell and Easton's ${ }^{27}$ investigation on Imperial College students undertaking their surgery module. These students preferred surgical teaching within general practices due to the learner-centred approach in teaching, more protected teaching time and regular access to suitable patients for acquiring clinical skills.

The success of community teaching in Leicester was analysed by Hastings et al. ${ }^{11}$ It was found that the improved quality of teaching by GP tutors was attributed to a higher proportion of GP tutors attending teachertraining courses. General practices were also found to have greater resource availability and NHS funding specifically allocated to support the teaching of medical undergraduates. All these factors placed hospital doctors at a disadvantage in preparing good-quality clinical teaching sessions in comparison to GPs.

\section{Impact assessment of CBE}

Studies of CBE impact on students bore the following themes: (1) Learning outcomes, (2) Behavioural changes to primary care and (3) Traits of future doctors. These are summarised in figure 2.

CBE also had an impact on participating doctors, staff, patients and medical schools. A summary of this is shown in figure 3 .

Impact on students: learning outcomes

Implementation of CBE in medical schools had a significant positive impact on medical students' learning outcomes. The following results provide evidence of the strong educational value among students: 11 studies showed that medical students gained insight into patientcentred medicine and continuity of care, which were 
Table 4 Summary of systematic review

\begin{tabular}{|c|c|c|c|c|c|c|}
\hline & University & Author (year) & Description of CBE & $\begin{array}{l}\text { Type of } \\
\text { evaluation }\end{array}$ & Evaluation findings & Evaluation method \\
\hline 1. & Aberdeen (University of) & $\begin{array}{l}\text { Sinclair et al } \\
(2006)^{32}\end{array}$ & $\begin{array}{l}\text { Years 1-3: GP-led patient-centred } \\
\text { tutorials and clinical sessions } \\
\text { Year 4: 5-week community-themed } \\
\text { clinical rotation } \\
\text { Year 5: optional 7-week general } \\
\text { practice attachment }\end{array}$ & $\begin{array}{l}\text { Impact } \\
\text { assessment }\end{array}$ & $\begin{array}{l}\text { Increase in students interested in pursuing a career in general } \\
\text { practice as curriculum progressed } \\
\text { Exposure to community settings had positive effect on students' } \\
\text { attitudes towards a career in general practice }\end{array}$ & $\begin{array}{l}\text { Questionnaire-Student } \\
\text { Survey }\end{array}$ \\
\hline 2. & $\begin{array}{l}\text { Barts and The London } \\
\text { School of Medicine and } \\
\text { Dentistry }\end{array}$ & $\begin{array}{l}\text { Nicholson et al } \\
(2001)^{31}\end{array}$ & $\begin{array}{l}\text { Year 4: Community-based Module } \\
\text { prior to obstetrics and gynaecology } \\
\text { hospital placement }\end{array}$ & $\begin{array}{l}\text { Implementation } \\
\text { assessment } \\
\text { Impact } \\
\text { assessment }\end{array}$ & $\begin{array}{l}\text { Adequate clinical exposure within the community } \\
\text { Variation in opportunities to gain relevant experience in clinical } \\
\text { exposure } \\
\text { Students found small-group learning and GP attitudes to be } \\
\text { beneficial to their learning } \\
\text { Multidisciplinary interaction enhanced their clinical experience } \\
\text { Successfully Incorporated specialty with community environment }\end{array}$ & $\begin{array}{l}\text { Questionnaire-Student } \\
\text { Feedback }\end{array}$ \\
\hline 3. & Birmingham (University of) & Parle et al (1999) ${ }^{7}$ & $\begin{array}{l}\text { Years 1-4: General practice practice } \\
\text { visits }\end{array}$ & $\begin{array}{l}\text { Implementation } \\
\text { assessment } \\
\text { Impact } \\
\text { assessment }\end{array}$ & $\begin{array}{l}\text { Students found GP tutors to be encouraging } \\
\text { GP tutors reported: } \\
\text { Enhanced development of both students and GPs } \\
\text { Organisational drawbacks }\end{array}$ & $\begin{array}{l}\text { Questionnaire-Student } \\
\text { Feedback }\end{array}$ \\
\hline 4. & Cambridge (University of) & $\begin{array}{l}\text { Alderson and } \\
\text { Oswald }(1999)^{33}\end{array}$ & $\begin{array}{l}\text { 15-month attachment to general } \\
\text { practice practice }\end{array}$ & $\begin{array}{l}\text { Implementation } \\
\text { assessment }\end{array}$ & $\begin{array}{l}\text { Adequate exposure of all clinical specialities was achieved } \\
\text { Individual experiences may vary due to variation in opportunities }\end{array}$ & Student log Diary \\
\hline 5. & Cambridge (University of) & $\begin{array}{l}\text { Oswald et al } \\
(2001)^{17}\end{array}$ & $\begin{array}{l}15 \text {-month attachment to general } \\
\text { practice practice }\end{array}$ & $\begin{array}{l}\text { Implementation } \\
\text { assessment } \\
\text { Impact } \\
\text { assessment } \\
\text { Cost assessment }\end{array}$ & $\begin{array}{l}\text { Course was feasible in terms of organisation and student logistics } \\
\text { Extended relationships with patients enriched students' clinical } \\
\text { experience } \\
\text { No difference in academic performance on formative assessments } \\
\text { between students undertaking community-based versus } \\
\text { hospital-based teaching } \\
\text { Reported costs were less than the average 'SIFT into the Future' } \\
\text { student-year }\end{array}$ & $\begin{array}{l}\text { Debriefing Sessions- } \\
\text { Student Feedback }\end{array}$ \\
\hline 6. & Cardiff University & $\begin{array}{l}\text { Grant and Robling } \\
(2006)^{24}\end{array}$ & Year 5: General practice attachment & $\begin{array}{l}\text { Needs } \\
\text { assessment } \\
\text { Impact } \\
\text { assessment }\end{array}$ & $\begin{array}{l}\text { All parties found the attachment to be positive } \\
\text { general practices felt more confident clinically through teaching } \\
\text { students } \\
\text { Primary care team felt team ethic was strengthened }\end{array}$ & $\begin{array}{l}\text { Discussion Meetings- } \\
\text { Primary Care Team } \\
\text { Feedback } \\
\text { Interviews-general practice } \\
\text { Feedback }\end{array}$ \\
\hline 7. & Dundee (University of) & Muir $(2007)^{25}$ & $\begin{array}{l}\text { Year 1-3: Patient Follow-up in the } \\
\text { community }\end{array}$ & $\begin{array}{l}\text { Impact } \\
\text { assessment }\end{array}$ & $\begin{array}{l}\text { Students were able to gain a better insight into patient-centred } \\
\text { medicine as a result of the attachment } \\
\text { Early exposure to patients evoked student enthusiasm }\end{array}$ & $\begin{array}{l}\text { Focus Group-Student } \\
\text { Interview }\end{array}$ \\
\hline 8. & Glasgow (University of) & $\begin{array}{l}\text { Davison et al } \\
(1999)^{6}\end{array}$ & $\begin{array}{l}\text { Year 1: Educational exercise of three } \\
\text { teaching sessions }\end{array}$ & $\begin{array}{l}\text { Needs } \\
\text { assessment }\end{array}$ & $\begin{array}{l}\text { Students found that learning objectives were met through } \\
\text { community-themed educational exercises }\end{array}$ & $\begin{array}{l}\text { Questionnaire-Student } \\
\text { Evaluation }\end{array}$ \\
\hline 9. & Glasgow (University of) & $\begin{array}{l}\text { Mullen et al } \\
(2010)^{26}\end{array}$ & $\begin{array}{l}\text { Year 1: Patient interviews in the } \\
\text { community }\end{array}$ & $\begin{array}{l}\text { Impact } \\
\text { assessment }\end{array}$ & $\begin{array}{l}\text { Integration of community-based exercise positively influenced } \\
\text { students' attitudes in regards to: } \\
\text { - Understanding of psychosocial model of illness } \\
\text { Development of empathy }\end{array}$ & $\begin{array}{l}\text { Questionnaire-Student } \\
\text { Evaluation }\end{array}$ \\
\hline 10. & Imperial College & $\begin{array}{l}\text { Powell and Easton } \\
(2012)^{27}\end{array}$ & $\begin{array}{l}\text { Year 3: 3-session surgical module } \\
\text { conducted by general practice tutors }\end{array}$ & $\begin{array}{l}\text { Implementation } \\
\text { Assessment }\end{array}$ & $\begin{array}{l}\text { Surgical teaching delivered by general practices was favourable } \\
\text { based on the following benefits: } \\
\text { Protected time for learning } \\
\text { Regular access to suitable patients } \\
\text { Learner-centred teaching } \\
\text { However GP lacked specialist knowledge, and teaching was not } \\
\text { directed by syllabus }\end{array}$ & $\begin{array}{l}\text { Focus group-Student } \\
\text { Interview }\end{array}$ \\
\hline
\end{tabular}




\begin{tabular}{|c|c|c|c|c|c|c|}
\hline & University & Author (year) & Description of CBE & $\begin{array}{l}\text { Type of } \\
\text { evaluation }\end{array}$ & Evaluation findings & Evaluation method \\
\hline 11. & King's College London & $\begin{array}{l}\text { Seabrook et al } \\
(1999)^{8}\end{array}$ & $\begin{array}{l}\text { Year 1: Healthcare Team Module } \\
\text { Year 2: Special Study Module }\end{array}$ & $\begin{array}{l}\text { Implementation } \\
\text { assessment } \\
\text { Impact } \\
\text { assessment }\end{array}$ & $\begin{array}{l}\text { Community-based courses are feasible and well-received by } \\
\text { students } \\
\text { Multidisciplinary teamwork is encouraged positively }\end{array}$ & $\begin{array}{l}\text { Questionnaires-Student } \\
\text { feedback } \\
\text { Small-group discussions- } \\
\text { Student feedback } \\
\text { Focus groups-Tutor } \\
\text { Feedback }\end{array}$ \\
\hline 12. & King's College London & $\begin{array}{l}\text { Gavin et al } \\
(2002)^{19}\end{array}$ & $\begin{array}{l}\text { Year 2-Community-based Special } \\
\text { Study Module }\end{array}$ & $\begin{array}{l}\text { Impact } \\
\text { assessment }\end{array}$ & $\begin{array}{l}\text { Student appreciation of: } \\
\text { Psychosocial needs of patients } \\
\text { - Inter-professional teamwork }\end{array}$ & $\begin{array}{l}\text { Questionnaire survey: } \\
\text { students and teaching } \\
\text { professionals }\end{array}$ \\
\hline 13. & Leeds (University of) & $\begin{array}{l}\text { Thistlethwaite and } \\
\text { Jordan }(1999)^{10}\end{array}$ & $\begin{array}{l}\text { Year 3: general practice-led days in } \\
\text { community setting }\end{array}$ & $\begin{array}{l}\text { Impact } \\
\text { assessment }\end{array}$ & $\begin{array}{l}\text { Early community exposure to patient-centred consultations allowed } \\
\text { students to: } \\
\text { Appreciate importance of patient-centred communication } \\
\text { Gain more confidence in their abilities } \\
\text { Direct observation and feedback from clinician was beneficial to } \\
\text { student learning }\end{array}$ & $\begin{array}{l}\text { Focus Groups-Student } \\
\text { Interviews }\end{array}$ \\
\hline 14. & Leeds (University of) & $\begin{array}{l}\text { Thistlethwaite } \\
(2000)^{13}\end{array}$ & $\begin{array}{l}\text { Year 3: general practice-led days in } \\
\text { community setting }\end{array}$ & $\begin{array}{l}\text { Implementation } \\
\text { assessment } \\
\text { Impact } \\
\text { assessment }\end{array}$ & $\begin{array}{l}\text { Positive feedback from students: } \\
\text { - Community environment allowed ease of patient-centre approach } \\
\text { Students now routinely ask about patient concerns } \\
\text { Positive feedback from general practices: } \\
\text { - Teaching was motivating and gratifying }\end{array}$ & $\begin{array}{l}\text { Questionnaire-Student } \\
\text { Feedback }\end{array}$ \\
\hline 15. & $\begin{array}{l}\text { Leeds (University of), } \\
\text { Sheffield (University of) and } \\
\text { Hull York Medical School }\end{array}$ & $\begin{array}{l}\text { Macallan and } \\
\text { Pearson }(2013)^{42}\end{array}$ & $\begin{array}{l}\text { Years 3-4: General practice } \\
\text { attachment }\end{array}$ & $\begin{array}{l}\text { Implementation } \\
\text { assessment }\end{array}$ & $\begin{array}{l}\text { general practice enthusiasm and engagement crucial to determining } \\
\text { the quality of the placement } \\
\text { Well-organised general practice were valued by students } \\
\text { Students felt that general practices needed to be better informed of } \\
\text { placement outcomes }\end{array}$ & $\begin{array}{l}\text { Focus Groups-Student } \\
\text { Interviews }\end{array}$ \\
\hline 16. & Leicester (University of) & $\begin{array}{l}\text { Lennox and } \\
\text { Petersen }(1998)^{30}\end{array}$ & Year 3: Patient Study & $\begin{array}{l}\text { Needs } \\
\text { assessment } \\
\text { Implementation } \\
\text { assessment } \\
\text { Impact } \\
\text { assessment }\end{array}$ & $\begin{array}{l}\text { Precourse needs assessment of CBE programme based on } \\
\text { students' opinions of: } \\
\text { Structure of course } \\
\text { Method of implementation } \\
\text { Assessment format } \\
\text { End-course impact assessment revealed that: Course effectively } \\
\text { achieves GMC recommendations for 'Tomorrow's Doctors' } \\
\text { End-Course Implementation assessment revealed that: } \\
\text { Continuation of the course was supported by all participants } \\
\text { (students, patients and agencies) }\end{array}$ & $\begin{array}{l}\text { Questionnaire-Student, } \\
\text { Patient and Agency } \\
\text { Feedback }\end{array}$ \\
\hline 17. & Leicester (University of) & $\begin{array}{l}\text { Hastings et al } \\
(2000)^{11}\end{array}$ & $\begin{array}{l}\text { Year } 3 \text { or } 4 \text { : General practice } \\
\text { practice-based teaching }\end{array}$ & $\begin{array}{l}\text { Implementation } \\
\text { assessment }\end{array}$ & $\begin{array}{l}\text { Comparison of practice-based \& hospital-based teaching with } \\
\text { respect to the 'teaching content' and the 'teaching processes } \\
\text { revealed students favouring practice-teaching in both respects }\end{array}$ & $\begin{array}{l}\text { Questionnaire-Student } \\
\text { Feedback }\end{array}$ \\
\hline 18. & Leicester (University of) & $\begin{array}{l}\text { Anderson et al } \\
(2003)^{21}\end{array}$ & $\begin{array}{l}\text { Year 3: Community placement and } \\
\text { Patient study }\end{array}$ & $\begin{array}{l}\text { Implementation } \\
\text { assessment } \\
\text { Impact } \\
\text { assessment }\end{array}$ & $\begin{array}{l}\text { Implementation assessment: } \\
\text { - Continuation of course was well-supported by students, patients } \\
\text { and staff } \\
\text { Impact assessment: } \\
\text { - Course effectively achieved students' learning objectives in } \\
\text { community education. } \\
\text { - Positive patient and staff experience in their involvement in } \\
\text { medical education }\end{array}$ & $\begin{array}{l}\text { Questionnaires-Student } \\
\text { and Patient Feedback } \\
\text { Focus Groups-Staff } \\
\text { Interviews }\end{array}$ \\
\hline 19. & Liverpool (University of) & $\begin{array}{l}\text { Watmough } \\
(2012)^{28}\end{array}$ & $\begin{array}{l}\text { Years 1-4: Community-based } \\
\text { teaching } \\
\text { Year 5: Community placement }\end{array}$ & $\begin{array}{l}\text { Implementation } \\
\text { assessment } \\
\text { Impact } \\
\text { assessment }\end{array}$ & $\begin{array}{l}\text { Implementation assessment: } \\
\text { Increased curriculum time on community-based teaching was } \\
\text { appreciated in terms of clinical skills practice, and understanding } \\
\text { the role of primary care }\end{array}$ & $\begin{array}{l}\text { Questionnaires and } \\
\text { Interviews-Student } \\
\text { Feedback }\end{array}$ \\
\hline
\end{tabular}


20. Liverpool (University of)

Watmough et al $(2012)^{43}$

21. Manchester (University of) Jones et al $(2002)^{20}$

22. Newcastle University Medical School

23. Royal Free and University College Medical Schools

tacy and Spencer (1999)

Walters et al

$(2003)^{22}$

24. Royal Free and University College Medical Schools

25. Sheffield (University of)

26. Sheffield (University of)

27. University College London

28. University College London

urray et al $(2001)^{16}$

29. University College London

O'Sullivan et al $(2000)^{12}$

Jones et al $(2005)^{23}$

Howe and lves $(2001)^{15}$

Howe $(2001)^{14}$

Coleman and Murray (2002) ${ }^{18}$ general practice placement

Years 1-4: Community-based teaching Year 5: Community placemen

Years 3-4: General practice teaching Impact in core modules

Year 5: Community placement

Year 2: Patient study projects

Year 4: Community education integrated in the psychiatry attachment

Intercalated BSc in Primary Health

Year 4:General practice placement

Year 4: General practice placement

assessment

general practice placement as part of Implementation the internal medicine clerkship assessment

Year 3: Community Medicine placement

Impact

Impact

assessment
Type of

Evaluation findings

Impact assessment:

- Reformed course achieved significantly better understanding on

the relationship between primary, social care and hospital care the relationship bet

- Graduates from reformed curriculum had more confidence in

clinical skills \& communication skills, but felt less well prepared with their medical knowledge

Overall positive impact on students' perception of preparedness in competencies and skills for entering professional practice. This

includes a significantly improved understanding of the role of primary care.

Students also had no disadvantage to graduates of traditional programme in terms of basic science and clinical knowledge programme in terms of basic science and clinical knowledge Patients have a positive perception of their role in community-b
teaching. They also feel that they benefited from participation Impact of participation in teaching on patients:

Mainly positive experience (more balanced doctor-patient

relationship, and some had therapeutic benefit)

- However a few patients found the teaching encounter distressing

Students saw benefit in:

Development of critical approach and skills relevant to medicine

- Adding depth to views on general practice and primary care

Increased exposure to primary and community care alters career

intention, and enhances the view of the role of primary care

Students value community-based learning which have the qualities

of:

- Person-centred clinical methods and learning contexts

- Positive attitude and committed general practice tutors and

primary care teams

Patients mainly felt positive about participating in community-based teaching.

However there were also negative aspects that may concern patients

There may also be shifts in the doctor-patient relationship

- Time spent on teaching and learning activities were similar in both settings

Supervised interaction with patients (which was experienced

mainly with the general practice) is perceived by students as the most educationally valuable and enjoyable activity

Patient-based learning was highly valued

Implementation assessment

- Basic clinical skills could be learnt in both settings, but general practice was better for learning of communication skills \&

psychosocial issues

aspact

General practice teaching was advantageous in terms of: quality of teaching, tutors' teaching attitude, teaching methods, course organisation.

Impact assessment revealed that:

- General practice enabled students to increase their confidence and competence
Evaluation method

Questionnaires-Student Feedback

Questionnaires-Student and Supervisor Feedback

Interviews

Questionnaire-Patien

Survey

Interviews-Patients,

Students and general

practice tutor Feedback

Interviews-Student

Feedback

Questionnaires-Student Feedback

Questionnaire-Studen

feedback

Interviews-Students and general practice tutor Feedback

Student Log Diary

Iterviews-Studen

Feedback

Focus Groups-Studen

Feedback 


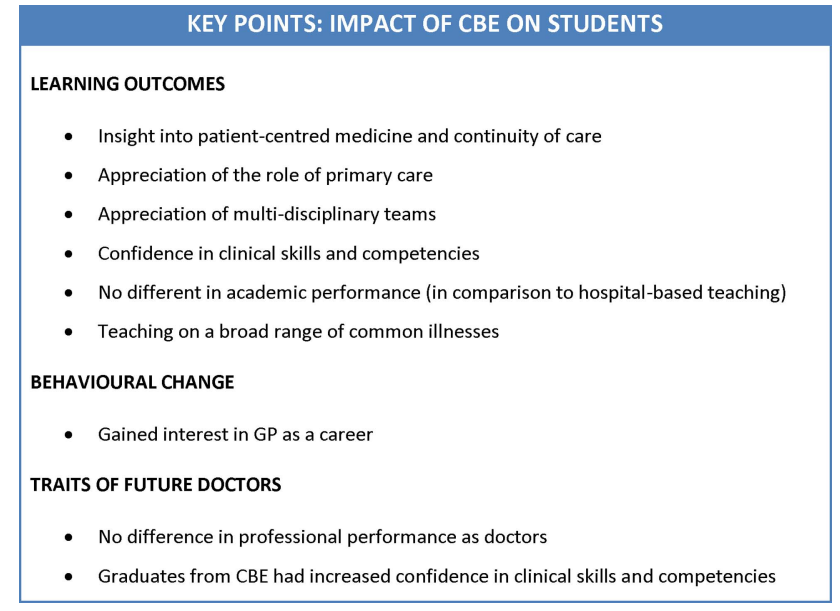

Figure 2 Key points: impact of community-based education on students.

learning outcomes that students viewed as important in their education. ${ }^{10} 13 \quad 17 \quad 19-212325262832$ This was measured quantitatively through questionnaires that were administered to students, supplemented by quantitative feedback gathered from focus groups and interviews.

Students' appreciation and understanding of the role of primary care was found in four studies. ${ }^{20} 212832$ This was revealed through questionnaires, where students rated the extent of their understanding of primary care and its relationship with other levels of care. Two studies reported the benefit of community placements in broadening the student's awareness of teamwork in multidisciplinary teams. ${ }^{19}{ }^{30}$ Another study reported the positive finding of successfully exposing students to a broad and varied range of clinical problems in a community setting. ${ }^{33}$

In comparison to hospital-based teaching, improved confidence in clinical skills and competencies was found to be a favourable outcome of CBE in four studies. ${ }^{10121920}$ This finding was derived from questionnaires and focus group interviews from students who had experienced CBE.

KEY POINTS: IMPACT OF CBE ON OTHER PARTICIPANTS IN CBE
IMPACT ON GP TUTORS
- Increased satisfaction; professional and personal development
- Teaching would be at the expense of practice commitments
IMPACT ON PATIENTS
- Sense of empowerment, a sense of balance in the doctor-patient relationship, and therapeutic
- benefit
- Some patients may react negatively to participation
IMPACT ON MEDICAL SCHOOL
- Able to create more learning opportunities for students
IMPACT ON HOSPITAL TUTORS
- Decreased focus on hospital-based teaching

Figure 3 Key points: impact of community-based education (CBE) on other participants in CBE.
Two studies found no difference in academic performance between students under CBE and 'traditional' hospital-based teaching. ${ }^{17}{ }^{20}$ One study of students who undertook a specialty placement in Obstetrics and Gynaecology also found that there was no difference in clinical performance as rated by their tutors, and no statistically significant difference in student final clerkship grades. ${ }^{34}$

Although most evaluations produced consistent evidence on the benefits of community teaching, two studies highlighted the lack of in-depth knowledge of specialist teaching when conducted by GP tutors: the significance of this finding was measured qualitatively through student interviews, ${ }^{27}$ and quantitatively through academic scores for the respective specialty modules. ${ }^{34}$

Impact on students: behavioural changes to primary care Two studies found that the implementation of CBE resulted in a reversal of negative attitudes towards primary care, and an increase of interest in general practice as a career option among students. ${ }^{23} 32$

\section{Impact on students: traits of future doctors}

Studies also showed that medical graduates from curricula with increased emphasis on community-based teaching were at no disadvantage to graduates from the traditional hospital-based teaching. ${ }^{17} 33$ Academically, graduates from a community-based curriculum performed as well as their counterparts on their final formative assessments. Moreover, graduates from curricula where community-based teaching had been offered had the advantage of increased confidence in communication skills and clinical skill competencies. This outcome of CBE was evaluated in three studies. ${ }^{17} 2028$ Two of these three studies additionally reported that graduates felt less confident in their medical knowledge on disease processes. $^{2028}$ However, there was no evident difference found in comparison to graduates of 'traditional' programmes of old medical curricula which had no CBE component when measured by academic results and feedback from educational supervisors. ${ }^{20} 28$

\section{Impact on others involved in CBE orogrammes}

In three studies, it was found that GP tutors and participating staff had both role satisfaction and development of professional and personal ethics. ${ }^{7} 1324$ Grant and Robling $^{24}$ also found strengthened team ethics between members of the primary healthcare team.

Doctors and staff, however, were found to have organisational issues in juggling community teaching with practice commitments. The expense of one over the other was described in CBE implemented by the University of Birmingham. ${ }^{7}$ The unfavourable outcome of blurred boundaries in the doctor-patient relationship was also reported as a concern in two studies. ${ }^{18} 22$

Five studies evaluated the positive patient outcomes of CBE: Four of these studies reported the beneficial sense of empowerment that patients gained from participating 
in community teaching. ${ }^{9} 212224$ The remaining study reported that patients developed feelings of altruism from helping medical students in their education. ${ }^{18}$

Apart from gaining a sense of empowerment, Walters $e t a l^{22}$ also reported the development of a more balanced doctor-patient relationship, and a therapeutic benefit for the patients as a result of talking to students about their medical condition.

Among these five studies on patient outcomes, two studies included further evaluations on the negative impact that resulted from patient participation. The negative outcomes comprised, reinforced feelings of illhealth which may be distressing or anxiety-provoking and concerns of breaching patient confidentiality. ${ }^{18} 22$

Powel $e t a l \mathrm{~s}{ }^{27}$ evaluation also shed light on the benefits that medical schools gained from tapping into teaching within the community. By doing so, medical schools were able to increase the availability of learning opportunities to medical students.

Two studies raised the possibility of the negative impact that CBE would have on hospital tutors. ${ }^{713}$ The concern raised in these studies was with regards to a shift of focus away from teaching conducted by hospitalbased tutors, and towards an emphasis on teaching in the community.

\section{Cost assessment of CBE}

Only one study evaluated the costs of running a community-based course. An evaluation of CBE in Cambridge revealed that the programme was cost-feasible as the total expenditure on one student-year of communitybased teaching was within the cost estimates of Service Increment for Teaching (SIFT) funding. ${ }^{17}$ The study also noted that the balance between placement costs and facilities costs stood at a ratio of approximately 2:1, which is a reverse of the traditionally allocated 1:4 ratio in SIFT funds. This finding implied that the traditional allocations for SIFT funds would be inappropriate when applied to community-based teaching.

\section{DISCUSSION}

This study was conducted to analyse the current provision of community-based education across undergraduate medical schools in the UK. All medical schools were found to offer some community-based teaching in their curricula, which falls in line with the recommendations of the WHO and the GMC which also follows the social demographic and political changes within the UK. Furthermore, a significant proportion of medical schools offered community-based teaching early in the medical course. The benefits of this early exposure is explored by Dornan et $a l l^{35}{ }^{36}$ where the opportunity to learn in context of clinical settings enabled students to develop an awareness of their interpersonal skills, attitudes and abilities.

In general, community-based teaching was wellreceived by medical students due to its good educational value on many levels of learning outcomes. It also gave students insight into the option of general practice as a future career. This is consistent with the direction of travel the UK healthcare workforce needs to address due to the changing demographics and the emphasis changing in healthcare delivery from management to prevention. Not only was community-based teaching of value to students, but it was also found to produce medical graduates of equal clinical skills and competencies to their counterparts who were taught under the 'traditional' hospital-based medical programme. ${ }^{17} 33$ This outcome is consistent with findings in Australian medical schools which showed that students generally did as well as or, in some areas of clinical competencies, even better than their counterparts who received hospital-based teaching. ${ }^{7}$ Community-based teaching in medicine was also beneficial to medical schools in maximising the sources of available learning opportunities for medical students. ${ }^{27}$ Moreover, community-based teaching in medicine was found to offer a unique opportunity to foster inter-professional learning - an outcome that is consistent with the political drivers for better patient care. $^{37}$

Although it was evident that community-based teaching has a vast array of benefits, several drawbacks were identified and underscored as challenges to the implementation of CBE. Studies reflected the challenges of general practice tutors lacking adequate knowledge in specialty areas, ${ }^{27}$ and community teaching having a negative impact on the delivery of health service in some general practices. ${ }^{7}$ Murray and Modell ${ }^{38}$ discuss possible solutions to these issues, such as the development of universitylinked practices that would scrutinise the effectiveness of teaching. It is imperative that these solutions are explored and tested in current CBE programmes so that the impact of programme drawbacks may be reduced. This would be the way-forward to strengthening the implementation of CBE in medical curricula.

An assortment of models were seen to be used for community-based teaching in the UK, where programmes varied in their methods of delivery, durations of exposure and points of undergraduate education at which the teaching was delivered. This is congruous with guidance from the GMC publication 'Tomorrow's Doctors', which states that it was for each medical school to design its own curriculum to suit its own circumstance. It should be noted that community-based education broadly encompasses varied delivery formats, including both clinical and non-clinical experiences. Unfortunately, the diversification of CBE poses a challenge for developing a standardised set of criteria for evaluating the outcomes of CBE. Consequently, it becomes difficult to establish a national framework for quality assurance of medical curricula, and to make recommendations for improving the implementation of CBE.

In order to achieve the expectations laid out for 'Tomorrow's Doctors', ${ }^{4}$ there is a principal need to define the competencies that are required to prevent 
illness and promote health in the primary care or community-based setting. Ladhani et $a l^{38}$ for example, categorised six themes of community-based education competencies within nursing and medicine: public health; cultural diversity; leadership and management; community development and advocacy; research and evidence-based practice; and generic competencies. Subsequently, a national framework may be derived from these key competencies so as to measure the effectiveness of community-based teaching in achieving these targeted goals.

The development of a national framework was explored and suggested by Cotton $e t a l^{39}$ where a list of criteria for quality practice-based teaching in the UK was consensually derived from views of medical educators and students at a national conference. However, since its development, there has been no literature found on the use of these criteria to objectively evaluate community-based education at a local, regional or national level. More work in this area should be encouraged to achieve a national standard for community-based education in the UK.

Little data was found on the cost implications of community-based teaching. Given the wide variations in the format of CBE programmes conducted across the $\mathrm{UK}$, it is difficult to make general conclusions about the cost impact of community-based teaching. Nonetheless the findings from Oswald $e t a l \mathrm{~s}^{17}$ study sets a benchmark for other similar community teaching within the UK. Oswald et al found that the absolute costs per student session of community teaching was within the budgets of SIFT funding. The cost-feasibility implied in this study is consistent with Murray et als $\mathrm{s}^{40} 1993$ study of the University College London teaching programme, where community teaching cost $£ 60$ per student session, comparing well with the SIFT provision of $£ 64$ per student session. However, Oswald et al discusses that the national formula for SIFT funds is inappropriate for community teaching due to a mismatch in the 2:1 ratio of placement costs and facilities costs in community teaching, versus the traditionally allotted 1:4 SIFT ratio between placement costs and facilities costs. SIFT funding to medical education institutions is traditionally divided to cater for the costs of clinical placements (about 20\%) and the costs of facilities (80\%). The 1995 Winyard Report specified that the use of SIFT funding would support teaching conducted in settings other than the main university hospital, such as in general practices and community settings. ${ }^{41}$ This report unfortunately failed to realise the inappropriateness of applying the 1:4 formula (for facilities and placement costs) in the context of primary care. The allocation of $80 \%$ SIFT funding to facilities would be disadvantageous to community-based teaching since this money will be retained for usage within the hospital setting. It is important that the provision of SIFT funding is reconsidered so that it suits a growing emphasis of community-based education in the medical curriculum and therefore help develop these settings as centres of education.
The strengths of our study are that it provides the most up-to-date picture of the UK landscape of community-based teaching in medical schools' and the fact that the literature review was conducted in a systematic way. The use of Rossi, Lipsey and Freeman's widely accepted approach to programme evaluation also ensured that programme evaluations in the literature were analysed comprehensively.

The weaknesses of the online survey are that it relied on data provided on the websites of medical schools which can occasionally be out of date and incomplete. The online survey also had the disadvantage of inconsistency in the extent of details provided online. For example, the online sources may not have mentioned details on clinical placements which are primarily hospital-based, but also provide supplementary clinical teaching within the community setting, (eg, shadowing of a community midwife in an Obstetrics and Gynaecology placement). To address these weaknesses, the method of information collection may be improved by contacting course administrators to obtain detailed and focused information on any community-based teaching that is offered to students in all the course modules. A weakness of the literature review is publication bias. The majority of the papers included in the review were written in support of CBE, and there are very few publications which focused on the disadvantages of CBE. This imbalance may have skewed our data in favour of CBE.

\section{CONCLUSION}

In this study, all undergraduate medical schools in the UK were found to offer some form of community-based teaching in their medical curriculum. The delivery of CBE varied broadly, but all forms of community teaching were generally found to be beneficial and was therefore well-received by students, patients, participating staff and medical schools. The challenges and cost issues of community teaching should also not be overlooked, and solutions to address these need to be explored such that the delivery of CBE may be improved.

Under the pressures of social demographics and political drivers to incorporate more community-based teaching in medical education, there is a need to ensure that CBE is delivered at acceptable quality standards for it to achieve its anticipated benefits. A national framework would need to be established to ensure these standards are met. This would then succeed to act as a standardised national guideline for evaluating the effectiveness of CBE programmes in developing professional competencies that are expected of 'Tomorrow's Doctors'.

Contributors WA came up with the concept of the study. NC performed the medical school online survey. SWWL and NT performed the literature review. SWWL, NC and NT wrote the draft of the manuscript. SWWL, NC, NT and WA were involved in editing the manuscript.

Funding This research received no specific grant from any funding agency in the public, commercial or not-for-profit sectors. 
Competing interests None.

Provenance and peer review Not commissioned; externally peer reviewed.

Data sharing statement No additional data are available.

Open Access This is an Open Access article distributed in accordance with the Creative Commons Attribution Non Commercial (CC BY-NC 4.0) license, which permits others to distribute, remix, adapt, build upon this work noncommercially, and license their derivative works on different terms, provided the original work is properly cited and the use is non-commercial. See: http:// creativecommons.org/licenses/by-nc/4.0/

\section{REFERENCES}

1. Our Priorities for 2013/14 [Internet]. London: Public Health England. Updated 26 April 2013. https://www.gov.uk/government/publications/ public-health-englands-priorities-for-2013-to-2014 (accessed Jan 2014).

2. Equity and Excellence: Liberating the NHS [Internet]. London: Department of Health. Updated July 2010. https://www.gov.uk/ government/publications/liberating-the-nhs-white-paper (accessed Jan 2014).

3. Community-based Education of Health Personnel: Report of a WHO Study Group [Internet]. Geneva: World Health Organisation. Updated November 1987. http://apps.who.int/iris/handle/10665/41714 (accessed Jan 2014).

4. Tomorrow's Doctors [Internet]. London: General Medical Council. Updated 2009. http://www.gmc-uk.org/education/undergraduate/ tomorrows_doctors_2009.asp (accessed Jan 2014).

5. Major SC, Booton P. Involvement of general practice (family medicine) in undergraduate medical education in the United Kingdom. J Ambul Care Manage 2008;31:269-75.

6. Davison $\mathrm{H}$, Capewell $\mathrm{S}$, Macnaughton J, et al. Community-oriented medical education in Glasgow: developing a community diagnosis exercise. Med Educ 1999;33:55-62.

7. Parle J, Greenfield S, Thomas C, et al. Community-based clinical education at the University of Birmingham Medical School. Acad Med 1999;74:248-53.

8. Seabrook MA, Lempp H, Woodfield SJ. Extending community involvement in the medical curriculum: lessons from a case study. Med Educ 1999;33:838-45.

9. Stacy R, Spencer J. Patients as teachers: a qualitative study of patients' views on their role in a community-based undergraduate project. Med Educ 1999;33:688-94.

10. Thistlethwaite JE, Jordan JJ. Patient-centred consultations: a comparison of student experience and understanding in two clinical environments. Med Educ 1999;33:678-5.

11. Hastings AM, Fraser RC, McKinley RK. Student perceptions of a new integrated course in clinical methods for medical undergraduates. Med Educ 2000;34:101-7.

12. O'Sullivan M, Martin J, Murray E. Students' perceptions of the relative advantages and disadvantages of community-based and hospital-based teaching: a qualitative study. Med Educ 2000;34:648-55.

13. Thistlethwaite JE. Introducing community-based teaching of third year medical students: outcomes of a pilot project one year later and implications for managing change. Educ Health 2000;13: 53-62.

14. Howe A. Patient-centred medicine through student-centred teaching: a student perspective on the key impacts of community-based learning in undergraduate medical education. Med Educ 2001;35:666-72.

15. Howe A, Ives G. Does community-based experience alter career preference? New evidence from a prospective longitudinal cohort study of undergraduate medical students. Med Educ 2001;35:391-7.

16. Murray E, Alderman $\mathrm{P}$, Coppola W, et al. What do students actually do on an internal medicine clerkship? A log diary study. Med Educ 2001:35:1101-7.

17. Oswald $\mathrm{N}$, Alderson $\mathrm{T}$, Jones $\mathrm{S}$. Evaluating primary care as a base for medical education: the report of the Cambridge Community-based Clinical Course. Med Educ 2001;35:782-8.

18. Coleman K, Murray E. Patients' views and feelings on the community-based teaching of undergraduate medical students: a qualitative study. Fam Pract 2002;19:183-8.
19. Gavin J, Lempp H, Elliman A, et al. Teaching in partnership: linking a medical school and a community trust. Br J Community Nurs 2002;7:32-6.

20. Jones A, McArdle PJ, O'Neill PA. Perceptions of how well graduates are prepared for the role of pre-registration house officer: a comparison of outcomes from a traditional and an integrated PBL curriculum. Med Educ 2002;36:16-25.

21. Anderson ES, Lennox AI, Petersen SA. Learning from lives: a mode for health and social care education in the wider community context. Med Educ 2003;37:59-68.

22. Walters K, Buszewicz M, Russell J, et al. Teaching as therapy: cross sectional and qualitative evaluation of patients' experiences of undergraduate psychiatry teaching in the community. BMJ 2003;326:740

23. Jones M, Singh S, Lloyd M. "It isn't just consultants that need a BSc": student experiences of an intercalated BSc in primary health care. Med Teach 2005;27:164-8.

24. Grant A, Robling M. Introducing undergraduate medical teaching into general practice: an action research study. Med Teach 2006;28:192-7.

25. Muir F. Placing the patient at the core of teaching. Med Teach 2007;29:258-60.

26. Mullen K, Nicolson M, Cotton P. Improving medical students attitudes towards the chronic sick: a role for social science research. BMC Med Educ 2010;10:84.

27. Powell S, Easton G. Student perceptions of GP teachers' role in community-based undergraduate surgical education: a qualitative study. JRSM Short Rep 2012;3:51.

28. Watmough $\mathrm{S}$. An evaluation of the impact of an increase in community-based medical undergraduate education in a UK medical school. Educ Prim Care 2012;23:385-90.

29. UK medical schools A-Z [Internet]. London: Medical Schools Council. http://www.medschools.ac.uk/Students/UKMedicalSchools/ Pages/UK-Medical-Schools-A-Z.aspx (accessed Nov 2013).

30. Lennox A, Petersen S. Development and evaluation of a community-based, multiagency course for medical students: descriptive survey. BMJ 1998;316:596-9.

31. Nicholson S, Osonnaya $\mathrm{C}$, Carter $\mathrm{YH}$, et al. Designing a community-based fourth-year obstetrics and gynaecology module: an example of innovative curriculum development. Med Educ 2001;35:398-403

32. Sinclair HK, Ritchie LD, Lee AJ. A future career in general practice? A longitudinal study of medical students and pre-registration house officers. Eur J Gen Pract 2006;12:120-7.

33. Alderson TS, Oswald NT. Clinical experience of medical students in primary care: use of an electronic log in monitoring experience and in guiding education in the Cambridge Community-based Clinical Course. Med Educ 1999;33:429-33.

34. Frattarelli LC, Kamemoto LE. Obstetrics and gynecology medical student outcomes: longitudinal multispecialty clerkship versus traditional block rotations. Am J Obstet Gynecol 2004;191:1800-4

35. Dornan T, Bundy $\mathrm{C}$. What can experience add to early medical education? Consensus survey. BMJ 2004;32:834-40.

36. Dornan T, Littlewood S, Margolis SA, et al. How can experience in clinical and community settings contribute to early medical education? A BEME systematic review. Med Teach 2006;28:3-18.

37. Hosny S, Kamel MH, El-Wazir Y, et al. Integrating interprofessiona education in community-based learning activities: case study. Med Teach 2013;35:S68-73.

38. Ladhani Z, Scherpbier AJ, Stevens FC. Competencies for undergraduate community-based education for the health professions-a systematic review. Med Teach 2012;34:733-43.

39. Cotton P, Sharp D, Howe A, et al. Developing a set of quality criteria for community-based medical education in the UK. Educ Prim Care 2009;20:143-51.

40. Murray E, Jinks V, Modell M. Community-based medical education: feasibility and cost. Med Educ 1995;29:66-71.

41. NHS Executive. SIFT into the future. Leeds: NHS Executive, 1995 (The Winyard Report)

42. Macallan and Pearson. Medical student perspectives of what makes a high-quality teaching practice. Educ Prim Care 2013 May;24 (3):195-201.

43. Watmough S et al. A comparison of self-perceived competencies of traditional and reformed curriculum graduates 6 years after graduation. Med Teach 2012;34(7):562-8. 